\title{
Effect of Nitrite Toxicity in Carbohydrate Metabolism to Fresh Water Fish Cirrhinus Mrigala
}

\author{
Yesudass Thangam \\ Assistant Professor \\ J.K.K.Nattraja college of Arts and Science, Kumarapalayam, Namakkal (Dt)
}

\begin{abstract}
The aim of the present study was to evaluate about the glucose, glycogen content in liver and muscle in fresh water fish Cirrhinus mrigala exposed to nitrite toxicity. Plasma glucose level of Cirrhinus mrigala exposed to sublethal toxicity (28.31) of nitrite exhibited a significant increase throughout the study period (Table 20 and Fig. 19). The significant increase in plasma glucose level was directly proportional to the exposure period showing a minimum percent increase of $3.69,5.55,13.34,20.53$ at the end of $7^{\text {th }} 14^{\text {th }}, 21^{\text {st }}, 28^{\text {th }}$, day and a maximum percent increase of 23.86 at the end of $35^{\text {th }}$ day. The changes in the liver glycogen content of fish Cirrhinus mrigala exposed to sublethal concentration of nitrite were presented in Table 21 and Fig. 20. The liver glycogen content was gradually increased as the exposure extended showing a percent increase of $1.24,1.34,2.04,3.64$ and 3.95 at the end of $7^{\text {th }}, 14^{\text {th }}, 21^{\text {st }}, 28^{\text {th }}$, and $35^{\text {th }}$ days respectively. Table 22 and Fig. 21 present the data on changes in the muscle glycogen content of fish Cirrhinus mrigala exposed to sublethal concentration of nitrite for 35 days. During the above treatment period the muscle glycogen content was decreased throughout the study period showing a percent decrease of $-7.44,-3.79,-10.37,-16.27,-31.03$ at the end of $7^{\text {th }}, 14^{\text {th }}, 21^{\text {st }}, 28^{\text {th }}$ and $35^{\text {th }}$ days, respectively.
\end{abstract}

Keywords: Cirrhinus mrigala, Nitrite, glucose, liver and muscle glycogen.

\section{Introduction}

Biochemical mechanisms involved in cellular detoxification are particularly relevant in understanding the deleterious effects of environmental pollutants (Lopes et al., 2001) and useful biomarkers of exposure to aquatic pollutants (Monterio et al., 2010). The use of biochemical methods offer promises in these areas viz, detection of states of stress, suggestion of modes of action and tentatively as tools to explain the metabolic basis for conventional fishery like growth. Measurement of plasma biochemical parameters is mostly used in clinical diagnosis of fish physiology to determine the general status of health (Osman et al., 2010). Nitrite is a natural component of nitrogen cycle in the ecosystems, and its presence in the environment is a potential problem due to its toxicity to animals. Aquatic animals are at higher risk of nitrite intoxication. Since nitrite in the ambient water can be actively taken up and can accumulate to very high concentrations in the body fluids. Studies on fish revealed that nitrite induced a large variety of physiological disturbances many of which contribute to toxicity (Jensen, 1995, 2003). Nitrite normally occurring in nature is no harmful to the environment, because they play an essential role in tissue metabolism and growth of plants and animals. Nitrite is endogenously produced as an oxidative metabolite of messenger molecule of nitric oxide (NO) and is naturally present at concentrations in most tissues of vertebrates (Kleinbongard et al., 2003; Bryan et al., 2005, Hansen and Jensen, 2010).

Carbohydrates are the primary and immediate source of energy (Lehninger, 1978). Glucose is an important source of energy in fish, especially in brain which obtains most of its energy from this carbohydrate (Lopez- Olmeda et al., 2009). Blood glucose and hepatic glycogen can be utilized as a parameter to stress response, as it rapid, practicable and quantitative reported the blood glucose and glycogen appeared to be sensitive indicator of environmental stress in fish and it has been widely monitored to study stress in fish (Teles et al., 2003). In fish carbohydrate play a major role as energy precursors under stress condition and changes in each of these blood component have been employed as useful general indicators (Yildiz and Benli, 2004). Under stress conditions, carbohydrate reserves are depleted to meet increased an energy demand (Arasta et al., 1996). Plasma glucose has been widely monitored to study stress in fish (Ramesh et al., 1994; Gagnon et al., 2006).

Many authors have reported a significant increase in glucose level in fishes exposed to various toxicant; mercury in Puntius conchonius (Gill and Pant, 1981), manganese in Tilapia nilotica (Ghazaly, 1992 a), arsenic in Channa punctatus (Hota, 1995), zinc in Salmo gairdneri (Watson and Mckeown ,1976), nitrite in Salmo gairdneri (Moraes et al.,2006), nickel in Tilapia nilotica (Ghazaly, 1992a) chromium and zinc in Salmo gairdneri (Strik et al., 1975), crude oil in Clupea pallasi (Kennedy and Farrell,2005), cadmium chloride in Catla catla (Sobha et al., 2007), mercury chloride in Catla catla (Martin Deva Prasath and Arivoli, 2008) and selenium in Clarias gariepinus (Abdel - Tawab et al., 2007a) in contrast decrease in plasma glucose level was reported by 
(Bhattacharya et al., 1987) in Channa punctatus exposed to industrial pollutants, Das et al., (2004a) in Catla catla exposed to nitrite, Velisek et al., (2007a) in rainbow trout Oncorhynchus mykiss due to deltamethrin to nitrite, (Velisek et al.,2005a) in Oncorhynchus mykiss exposed to copper and Siikavuopio and saether (2006) in Atlantic cod exposed to nitrite. Sometimes no significant changes in plasma glucose may be observed, because under stress the fish is rapidly consuming energetic substrates.

Similar to plasma glucose, change in the glycogen level in tissues could indicate the health status of fish populations. Liver and muscle glycogen responses appear particularly suitable for measuring stressful level of pollutants and have long been used as indicators of stress in fish (Ramesh and saravanan 2008 ; Ramesh et al., 1994, Glover et al., 2007). Significant decrease in tissue glycogen content of liver and muscle of fish exposed to various toxicants has been reported previously by many authors; in Tilapia mossambica treated with malathion (Sahib et al., 1982), in Brycon cephalus exposed to foliodol 600 (Aguiar et al., 2004), in euryhaline fish, Oreochromis mossambicus exposed to monocrotophos (Venkateswara Rao, 2006), in Punctatus exposed to lambda cyhalothrin and permethrin (Saxena and Gupta, 2005) and in Clarias batrachus exposed to cypermethrin (Begum, 2005). However, a increase in tissue glycogen level has been reported in Anguilla anguilla exposed to lindane (Ferrando and Anderu-Moliner, 1991) in Clarias batrachus exposed to organophosphate insecticide (Begum and Vijayaraghavan, 1996), and in Cyprinus carpio exposed to herbicide 2,4- Diamim ( Oruc-and Uner,1999). On the other hand, no changes in tissue glycogen level were noted in Anguilla Anguilla when exposed to the pesticide fenitotrion) Sancho et al., 1997).

Freshwater fish take up $\mathrm{No}_{2}$ Primarily across the gill. Nitrite accumulates in plasma, gill, liver, brain, spleen, muscle, etc., similar to the bio- accumulation of a pollutant and its effect in fish tissues and their immune system responses are very similar to those of the pollutant. Nitrite can actually be found in high concentrations in plasma of fish exposed to high nitrite levels (Margiocco et al., 1983). Nitrite accumulation causing tissue damage has been reported in fish (Arillo et al., 1984). Although an enormous amount of literature is available on nitrite effects on fish, information on the effects on biochemical profiles in fish and particularly in the Indian major carps is almost negligible. Hence the present investigation is aimed to assess the toxicity of nitrite in plasma glucose, liver glycogen and muscle glycogen activity of an Indian major carp Cirrhinus mrigala in order to understand the mode of action, stress response and using of these parameters as suitable biomarkers for nitrite toxicity.

\section{Materials And Methods}

Glucose level in plasma of Cirrhinus mrigala were estimated. The Changes in physico-chemical characteristics, such as temperature, $\mathrm{pH}$, dissolved oxygen, alkalinity, hardness, salinity, calcium and magnesium of experimental water were recorded throughout the experimental period. Fresh water fish Cirrhinus mrigala, weighing 5.0-6.0 gm and measuring 7-8 cm were collected from Tamilnadu Fisheries Development corporation, Aliyar fish farm, Aliyar, Tamilnadu, India. Fish of same age and size which hatched from the same lot of eggs were collected, the age of the fish being 2 to 3 months old. They were safely brought to the laboratory in well packed polythene bags containing aerated water and stocked in a large cement tanks (36' x18'x19'). Fish were acclimatized for about 20 days before the commencement of the experiment. During acclimatization period, fish were fed with ad libitum, with rice bran and ground nut oil cake in the form of dough once in daily. Water replaced every $24 \mathrm{~h}$ after feeding in order to maintain a healthy environment for the fish. This ensures sufficient oxygen supply for the fish and the environment is devoid of any accumulated metabolic waste. The feeding was withheld for $24 \mathrm{~h}$ before the commencement of the experiment and to keep the specimens in the same metabolic state. The fish were introduced into glass aquarium (26'x18'x18.5') $\mathrm{cm}$ which was washed thoroughly and maintained in the laboratory. Separate circular plastic tubs of 50 litres of water capacity were taken and different concentrations of nitrite were added. 10 healthy fishes were introduced into each tub. A control tub (no toxicant) with 50 litres of water and 10 fishes were also maintained. Three replicates were maintained for each concentration groups. The mortality/ survival of fish in control and nitrite treated tubs was recorded after $24 \mathrm{~h}$ and the concentration at which $50 \%$ mortality of fish occurred was taken as the median lethal concentration (Lc50) for $24 \mathrm{~h}$ which was $28.31 \mathrm{ppm}$. A similar experimental set up was also maintained to determine the median lethal concentration of sodium nitrite to fish Cirrhinus mrigala for $96 \mathrm{~h}$. The test water was renewed at the end of $24 \mathrm{~h}$ and freshly prepared solution was added to maintain the concentration of sodium nitrite at a constant level. The median lethal concentration (Lc50) of sodium nitrite for 96h was found to be $19.952 \mathrm{ppm}$. The median lethal concentration of nitrite was calculated by Probit analysis method (Finney, 1978). The sublethal toxicity was conducted at $1 / 10^{\text {th }}$ of Lc50 of $24 \mathrm{~h}$ value $(2.831) \mathrm{ppm}$.

The data observed in the experiment were statistically analysed for the calculation of standard error of mean (SEM). One way ANOVA and Duncan multiple range test for individual group with comparison was administered for testing the hypothesis. The data shown the average two replicates \pm SE and statistical significance was tested at $\mathrm{P}<0.05$ level. 


\section{Estimation Of Plasma Glucose}

PRINCIPLE

Plasma glucose was estimated by O-Toluidine method (Cooper and Mc Danial, 1970).

Glucose reacts with O-Toluidine in the presence of acetic acid to from a green colour derivative which is measured at $630 \mathrm{~nm}$ by using UV Spectrophotometer.

REAGENT UTILIZED

Reagent 1 : O-Toluidine colour reagent

PROCEDURE

Reagent 2 : Glucose standard, $100 \mathrm{mg} \%$

Tubes were taken and marked as Blank (B), Control (C), Test (T) and Standard (S). To each Test tube 5 $\mathrm{ml}$ of Reagent-1 (O-Toluidine colour reagent) was added. $0.1 \mathrm{ml}$ of distilled water was added to the test tube marked 'B' (Blank). Similarly, $0.1 \mathrm{ml}$ of plasma from control and nitrite treated fish was added to test tube marked as ' $\mathrm{C}$ ' (Control) and ' $\mathrm{T}$ ' (Test) respectively. Then $0.1 \mathrm{ml}$ of Reagent -2 (Glucose standard) was added to the test tube marked as S (Standard). The contents in the tubes were mixed well and heated in boiling water for 10 minutes. Then, the tubes were cooled under running tap water for 5 minutes and the optical density (O.D) of the test samples were measured at $630 \mathrm{~nm}$ within 30 minutes against Blank (B) using UV Spectrophotometer.

\section{Calculation}

O.D. Of the test
$\begin{array}{r}\text { Plasma glucose in } \mathrm{mg} / 100 \mathrm{ml}= \\ \text { O.D. of the Standard }\end{array}$

\section{Estimation Of Liver And Muscle Glycogen}

PRINCIPLE

Estimation of liver and muscle glycogen was done by anthrone method (Samseifter et al., 1949).

Sulphuric acid of the reagent causes dehydration of sugar to furfural derivatives which then presumably condenses with anthrone to from blue colour compound which is measured in UV Spectrophotometer at $620 \mathrm{~nm}$ wavelength.

REAGENTS

REAGENT 1: ANTHRONE REAGENT

$0.2 \mathrm{~g}$ of anthrone and few crystals of thiourea were dissolved in $100 \mathrm{ml}$ of $95 \%$ sulphuric acid by using a standard flask.

REAGENT 2: 30\% POTASSIUM HYDROXIDE SOLUTION

$30 \mathrm{~g}$ of potassium hydroxide was dissolved in distilled water and make up to $100 \mathrm{ml}$ in a standard flask. REAGENT 3: STANDARD GLUCOSE PROCEDURE

$10 \mathrm{~g}$ of glucose was dissolved in distilled water and made up to $100 \mathrm{ml}$ in a standard flask.

The weighed tissues (liver and muscle) were dropped in separate test tubes marked as 'Control' (C) and 'Test' (T) tubes which containing $3 \mathrm{ml}$ of $30 \%$ potassium hydroxide solution (Reagent-2). The tissues were digested by heating the test tubes for 20 minutes. After cooling, the digest was transferred quantitatively to 100 $\mathrm{ml}$ standard volumetric flask and diluted up to the mark with distilled water. From this, $5 \mathrm{ml}$ of aliquots from each tissue digest were taken for estimation. $5 \mathrm{ml}$ of working standard glucose solution (Reagent 3 ) containing $100 \mu \mathrm{g}$ of glucose and blank ( $5 \mathrm{ml}$ of distilled water) were also prepared.

Then $10 \mathrm{ml}$ of the anthrone reagent (Reagent-1) was delivered from the fast flowing pipette and they were mixed by swirling the test tube in a cold water bath. Then they were heated for 10 minutes in boiling water and again cooled. Using UV Spectrophometer the optical densities (O.D) of all the tubes were measured against Blank (B) at $620 \mathrm{~nm}$ wavelength.

\section{Calculation}

Glycogen in aliquots

$$
\begin{array}{r}
\text { O.D. Of the test } \quad 100 \\
100(\mu \mathrm{g} / \mathrm{ml} \text { of digest) }=\text {--.- } \\
\text { O.D. of the Standard } \quad 1.11
\end{array}
$$

1.11 is the Morris conversion factor that is used for the conversion of glucose to glycogen.

\section{Results}

The Plasma glucose level of Cirrhinus mrigala exposed to sublethal toxicity (28.31) of nitrite exhibited a significant increase throughout the study period (Table 20 and Fig. 19). The significant increase in plasma glucose level was directly proportional to the exposure period showing a minimum percent increase of 3.69 , $5.55,13.34,20.53$ at the end of $7^{\text {th }}, 14^{\text {th }}, 21^{\text {st }}, 28^{\text {th }}$, days and a maximum percent increase of 23.86 at the end of $35^{\text {th }}$ day. There were significant $(P<0.05)$ variation among the treatments $\left(F_{1}, 40=130.28 ; p<0.05\right)$, periods 
$\left(\mathrm{F}_{4,40}=89.19 ; \mathrm{P}<0.05\right)$ and their interactions $(\mathrm{F} 4,40=113.20 ; \mathrm{P}<0.05)$. The changes in the liver glycogen content of fish Cirrhinus mrigala exposed to sublethal concentration of nitrite were presented in Table 21 and Fig. 20. The liver glycogen content was gradually increased as the exposure extended showing a percent increase of $1.24,1.34,2.04,3.64$ and 3.95 at the end of $7^{\text {th }}, 14^{\text {th }}, 21^{\text {st }}, 28^{\text {th }}$, and $35^{\text {th }}$ days respectively. There were significant $(\mathrm{P}<0.05)$ variations among the treatments $\left(\mathrm{F}_{1,40}=103.80 ; \mathrm{P}<0.05\right),\left(\mathrm{F}_{4,40}=90.95 ; \mathrm{P}<0.05\right)$ and their interactions $\left(\mathrm{F}_{4,40}=48.01 ; \mathrm{P}<0.05\right)$. Table 22 and Fig. 21 present the data on changes in the muscle glycogen content of fish Cirrhinus mrigala exposed to sublethal concentration of nitrite for 35 days. During the above treatment period the muscle glycogen content was decreased throughout the study period showing a percent decrease of $-7.44,-3.79,-10.37,-16.27,-31.03$ at the end of $7^{\text {th }}, 14^{\text {th }}, 21^{\text {st }}, 28^{\text {th }}$ and $35^{\text {th }}$ days, respectively. There were significant $(\mathrm{P}<0.05)$ variation among the treatments $\left(\mathrm{F}_{\mathrm{F}, 40}=7396.45 ; \mathrm{P}<0.05\right)$, periods $\left(\mathrm{F}_{1,40}=1890.87 ; \mathrm{P}<0.05\right)$ and their interactions $\left(\mathrm{F}_{4,40}=848.80 ; \mathrm{P}<0.05\right)$.

\begin{tabular}{|c|c|c|c|}
\hline \multirow{2}{*}{$\begin{array}{c}\text { Exposure period } \\
\text { (in days) }\end{array}$} & \multicolumn{3}{|c|}{ Plasma glucose $(\mathrm{mg} / 100 \mathrm{ml})$} \\
\hline & Control & Experiment & Percent change \\
\hline 7 & $99.94 \pm 0.176 \mathrm{ab}$ & $103.63 \pm 0.183 \mathrm{e}$ & +3.69 \\
\hline 14 & $101.32 \pm 1.097 \mathrm{a}$ & $106.94 \pm 0.132 \mathrm{~d}$ & +5.55 \\
\hline 21 & $100.99 \pm 1.376 \mathrm{ab}$ & $114.46 \pm 0.123 \mathrm{c}$ & +13.34 \\
\hline 28 & $99.20 \pm \theta .339 \mathrm{~b}$ & $119.57 \pm 0.099 b$ & +20.53 \\
\hline 35 & $99.552 \pm 0.297 \mathrm{ab}$ & $123.30 \pm 0.141 \mathrm{a}$ & +23.86 \\
\hline Treatment $(\mathrm{T})$ & \multicolumn{3}{|c|}{$130.28^{* *}$} \\
\hline Period (P) & \multicolumn{3}{|c|}{$89.19^{* *}$} \\
\hline TXP & \multicolumn{3}{|c|}{$113.20^{* *}$} \\
\hline
\end{tabular}

Values are mean \pm S.E. of five individual observations. ( + ) Denotes percent increase ove control. ${ }^{* *}$ Significant at $5 \%$ level. Means in a column bearing same letter(s) are significantly different according to DMRT $(\mathrm{P}>0.05)$.

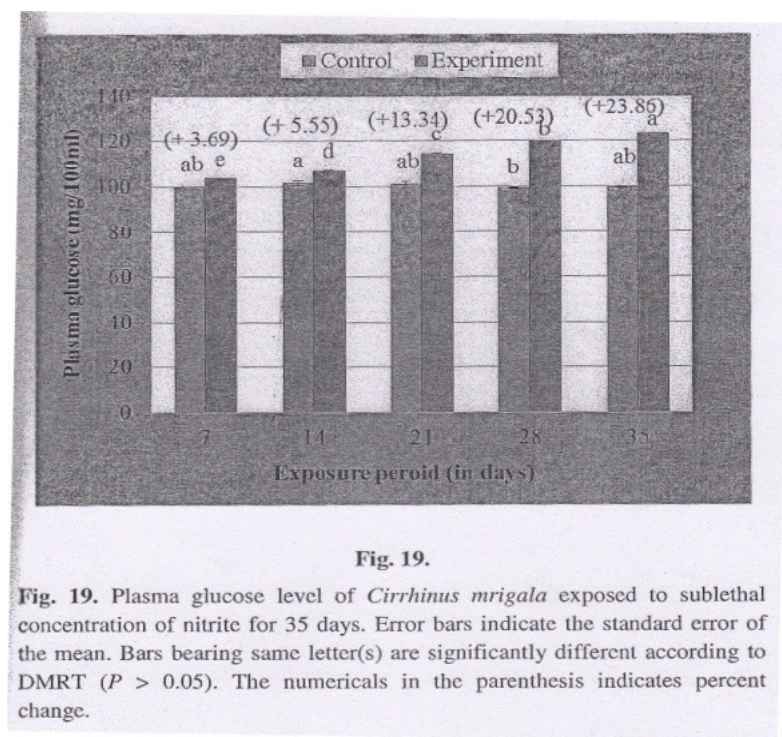


Table 21. Changes in the liver glycogen content of Cirrhinus mrigala exposed to sublethal concentration of nitrite for 35 days

\begin{tabular}{crrr}
\hline \multirow{2}{*}{$\begin{array}{c}\text { Exposure period } \\
\text { (in days) }\end{array}$} & Control & Experiment & Percent change \\
\cline { 2 - 4 } & $305.44 \pm 0.840 \mathrm{c}$ & $309.22 \pm 0.057 \mathrm{e}$ & +1.24 \\
14 & $306.88 \pm 0.310 \mathrm{ab}$ & $311.01 \pm 0.139 \mathrm{~d}$ & +1.34 \\
21 & $306.44 \pm 0.335 \mathrm{c}$ & $312.68 \pm 0.047 \mathrm{c}$ & +2.04 \\
28 & $305.42 \pm 0.662 \mathrm{bc}$ & $316.52 \pm 0.095 \mathrm{~b}$ & +3.64 \\
35 & $307.68 \pm 0.042 \mathrm{a}$ & $319.82 \pm 0.025 \mathrm{a}$ & +3.95 \\
\hline Treatment (T) & & $1003.80^{* *}$ & \\
Period (P) & & $90.95^{* *}$ & \\
TXP & & $48.01^{* *}$ \\
\hline
\end{tabular}

Values are mean \pm S.E. of five individual observations. $(+)$ Denotes percent increase over control.**Significant at $5 \%$ level. Means in a column bearing same letter(s) are significantly different according to DMRT $(\mathrm{P}>0.05)$.

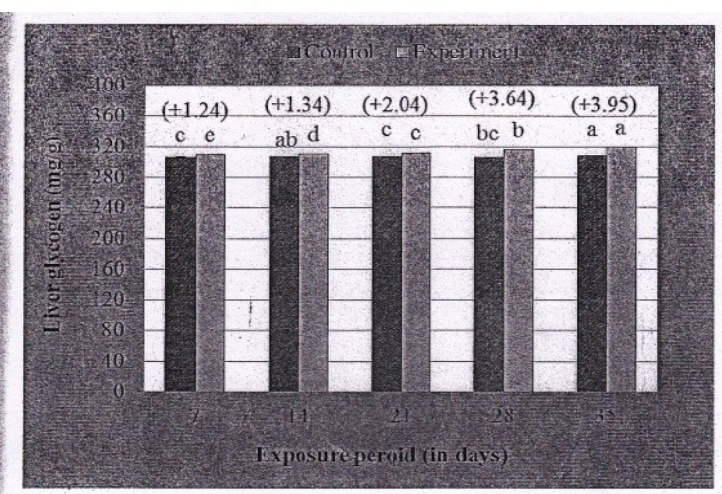

Fig. 20.

Fig. 20. Liver glycogen content of Cirrhinus mrigala exposed to subletha concentration of nitrite for 35 days. Error bars indicate the standard error of the mean. Bars bearing same letter(s) are significantly different according to DMRT $(P>0.05)$. The numericals in the parenthesis indicates percent change.

Table 22. Changes in the muscle glycogen content of Cirrhinus mrigala exposed to sublethal concentration of nitrite for 35 days

\begin{tabular}{crrc}
\hline \multirow{2}{*}{$\begin{array}{c}\text { Exposure period } \\
\text { (in days) }\end{array}$} & Control & Experiment & Percent change \\
\cline { 2 - 4 } 7 & $118.15 \pm 0.051 \mathrm{a}$ & $115.66 \pm 0.278 \mathrm{a}$ & -7.44 \\
14 & $124.16 \pm 0.434 \mathrm{~b}$ & $113.67 \pm 0.398 \mathrm{~b}$ & -3.79 \\
21 & $114.58 \pm 0.270 \mathrm{c}$ & $102.69 \pm 0.091 \mathrm{c}$ & -10.37 \\
28 & $115.13 \pm 0.057 \mathrm{c}$ & $96.39 \pm 0.442 \mathrm{~d}$ & -16.27 \\
35 & $114.88 \pm 0.046 \mathrm{c}$ & $79.24 \pm 0.393 \mathrm{e}$ & -31.03 \\
\hline Treatment (T) & & $7396.45^{* *}$ & \\
Period.(P) & & $1890.87^{* *}$ \\
TXP & & $848.80^{* *}$ \\
\hline
\end{tabular}

Values are mean \pm S.E. of five individual observations. (-) Denotes percent decrease over control. ${ }^{* *}$ Significant at $5 \%$ level. Means in a column bearing same letter(s) are significantly different according to DMRT $(\mathrm{P}>0.05)$. 


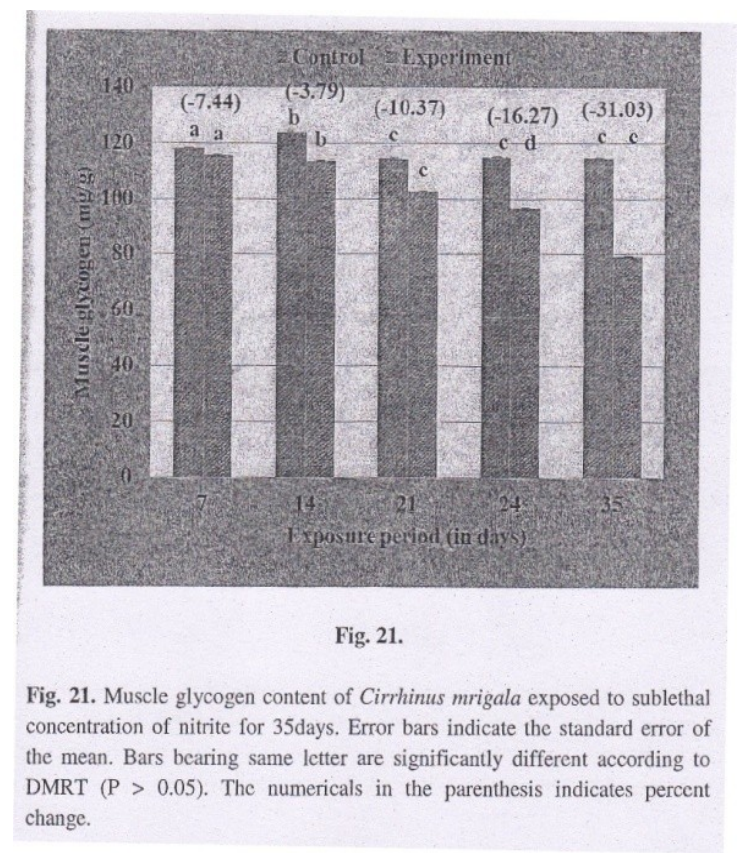

\section{Discussion}

The biochemical and physiological mechanisms in an organism play an important role during stress conditions. In general the presence of toxicants in aquatic media exerts its effect at cellular or molecular level which results in significant changes in biochemical parameters. The influence of stressors on carbohydrate metabolism of fish includes alterations in glucose, glycogen, and lactic acid content. Among these the blood glucose level has been used as an indicator of environmental stress and reflected the changes in carbohydrate metabolism under hypoxia and stress conditions (Kavitha et al., 2010). Carbohydrates are the main source of energy in many organisms and their reserve used to meet energy demand in stress condition. Stress response in fish involves energy demanding processes and glucose is an important energy source to the metabolism in tissue as the brain, heart, blood cells, and gills (Mommsen et al., 1999). Glucose is one of the most important sources of energy for the animals and glucose has been studied as an indicator of stress caused by physical factors in particular pollutants. Fish have been described as glucose intolerant, as hyperglycemia after a glucose load can last for several hours, even more than a day. However, these effects seen to be related for several hours, even more importantly to feeding habits (Moon, 2001).

Variation of blood glucose levels under different environmental and physiological conditions and the formation of lactate could be expected if anaerobic metabolism occurs (Halls and VanHam, 1998). Increased plasma glucose is an adaptive response to a stressor (Barton and Iwama, 1991), and environmental conditions that impose stress to the fish should therefore be expected to give increased blood plasma levels of glucose (Siikavuopio and Seather, 2006). Hyperglycemia is a typically associated with an increased metabolic rate, which is accelerated by both acute and chronic stress (Barton, 1988), because the stress response in fish is an energy demanding process. Nakno Tomlinson et al (1967) observed that all types of stress elevated the secretion of catecholamine which in turn increased the breakdown of glycogen and elevated blood glucose level.

The significant increase in plasma glucose level in C.carpio during acute and sublethal lindane treatment may be due to gluconeogenesis to provide energy for the increased metabolic demands imposed by the pesticide lindane (Saravanan et al., 2011). An elevation of blood glucose level in Catla catla during sublethal arsenic treatment might be due to gluconeogenesis to provide energy for increased metabolic demands imposed by sodium arsenate stress (Kavitha et al., 2010). In addition, hypothalamo-pituitary interrenal axis, stimulate by stressors elevated blood levels of cortisol which in turn leads to lipolysis, glycogenolysis and gluconeogenesis to provide energy under stress conditions (Hontela et al., 1993). The hyperglycemic condition observed in many teleost release condition is mainly mediated by effect of catecholamines on glucose release from liver (main carbohydrate store in fish) (Van Raaji et al., 1995).

Elevated glucose concentrations after long-term nitrite exposure have also been measured in Atlantic cod (Siikavuopio and Saether, 2006). Even at the lowest concentration $\left(0.01 \mathrm{mg} / \mathrm{L} \mathrm{NO}{ }_{2}\right)$, increase in glucose were detected in comparison with the control group (Kroupova et al., 2008). Hypoxia at tissue level affects the normal respiratory metabolism shifting it from aerobiosis to anaerobiosis (Philip et al., 1995; Smet and Blust, 2001) to supply greater energy for increased respiratory metabolism. Nitrite induced hypoxia, as indicated in the fingerlings, is therefore expected to increase the blood glucose. In the present study the observed increase of 
plasma glucose level during acute and sublethal treatment indicates a stress response triggered by the presence of nitrite in water or might be due to hypoxic condition caused by the nitrite in water.

Glycogen is the main reserve source of energy for animals during normal metabolism and their content in liver and muscle of fish exposed to chemical substances may indicate the health condition of the fish (Saravanan et al., 2011). They also reported that during unfavourable environmental situation the normal metabolism is affected which in turn leads to alteration in the glycogen reserve of fish. The significant increase in liver and muscle glycogen content during sublethal lindane treatment may indicate an adaptation of fish to lindane toxicity or impairment in the carbohydrate metabolism (Saravanan et al., 2011). Sastry and Siddiqui (1984) reported that liver glycogen level was increased in quinalphos exposed fish indicating a decrease in the rate of glycogenolysis. In the present study also the significant increase in liver and muscle glycogen during acute and sublethal treatments indicates impairment in the carbohydrate metabolism or a decrease in the rate of glycogenolysis

Generally depletion of glycogen level under stress condition may indicate an expression of an initial regulatory step resulting an increase in the intermediary metabolism. The reduction in glycogen content Cyprinus carpio during acute and sublethal lindane treatment indicates the utilization of stored glycogen to meet the high energy requirement under the lindane stress (Saravanan et al., 2011). The reduction of hepatic and muscular glycogen in Silver catfish exposed to high nitrite levels at different $\mathrm{pH}$ may indicate that stress generated by ammonia toxicity is accompanied by a rapid degradation of tissue glycogen. In fact, carbohydrates stored in liver and muscles are the first nutrients used in response to stress conditions (Vijayavel et al., 2006). Lower glycogen levels in liver and muscle were also observed in other freshwater fishes exposed to high $\mathrm{NH}_{3}$ levels $(1-4 \mathrm{mg} / \mathrm{L}$ ) (Miron et al., 2008). Depletion of glycogen may be due to direct utilization for energy generation, a demand caused by latex-induced hypoxia (Tiwari and Singh, 2005). Fish white muscles constitute more than $50 \%$ of the whole body mass, and anaerobic processes require glycogen for their action (Knox et al., 1980). Probably in the exposure to elevated NH3levels a hypoxic condition was generated and fish developed a preference for anaerobic glycogen breakdown (Miron et al., 2008). In the present study the significant decrease in muscle glycogen level during sublethal treatment may indicate that stress generated by nitrite toxicity is accompanied by a rapid degradation of tissue glycogen.

\section{References}

[1]. Abdel-Tawwab, M., Mousa, M.A.A., Ahmad, M.H., Sakr, S.F., 2007. The use of calcium pre-exposure as a protective agent against environmental copper toxicity for juvenile Nile tilapia, Oreochromis niloticus. Aquaculture, 264(1-40), 236-246.

[2]. Aguiar, L.H., Moraes, G. Avilez, I.M., Altran, A.E. and correa, C.F.2004. Metabolical effects of folidol 600 on the neotropical freshwater fishmatrinxa, Bryconcephalus. Environ.Res., 95, 221-230.

[3]. Arasta. T., Bais, V.S., Thakur, P., 1996. Effect of nuvan on some biological parameters of Indian catfish, Mystus vittatus.J. Environ. Biol., 17(2), 167-169.

[4]. Arilla, A., Gaino, E., Margiocco, C., Mensi, P.,schenone, G., 1984.Biochemical and ultrastructural effects of nitrite in rainbow trout: liver hypoxia as the root of the acute toxicity mechanism. Environ. Res. 34, 135-154.

[5]. Barton, B.A., 1988. Endocrine and metabolic responses of fish to stress. Int. Assoc. Aquat. Anim. Med Proc., $19,41-5$.

[6]. Barton. B.A., Iwama, G.K., 1991. Physiological changes fish from stress in aquaculture with emphasis on the response and effects of corticosteroids. Ann. Rev. Fish Dis., 1, 3-26.

[7]. Begam. G., 2005. Alteration in protein metabolism of muscle tissue in fish, Clarias batrachus (Linn) by commercial grade dimethoate. Bull. Environ. Contam. Toxicol., 57, 223-228.

[8]. Begum, G., Vijayaraghavan, s., 1996. Toxicity of an organophosphate insecticide on total soluble and structural proteins in the branchial tissue of an air breathing fish, Clarius batrachus (Linn.).J. Aquat. Biol., 9(1-2), 99-100.

[9]. Bhattacharya, T., Ray, A.K., Bhattacharya, S., 1987. Blood glucose and hepatic glycogen. Interrelationship in Channa punctatus (Bloch). A parameter of non-lethal toxicity bioassay with industrial pollutants. Indian J. Exp. Biol., 25, 539-541.

[10]. Cooper, G.R., McDaniel, V., 1970. Standard methods of clinical chemistry. Academic, New York, 159.

[11]. Das, P.C., Ayyappan, S., Das B.K., jena, J.K., 2004a. Nitrite toxicity in Indian major carps: sublethal effect on selected enzymes in fingerlings of catla catla, Labeo rohita and Cirrhinus mrigala. Comp Biochem. Physiol. C, 138, 3-10.

[12]. Ferrando, M.D., Andreu-Moliner, E., 1991. Changes in selected biochemical parameters in the brain of the fish, Anguilla augilla(L.), exposed to lindane. Bull. Environ. Contam. Toxicol., (3), 47.

[13]. Finney, D.J., 1978. Statistical Method in Biological Assay ( $3^{\text {rd }}$ Ed), Cambridge University Press, London, pp. 508.

[14]. Gagnon, A., jumarie, C., Hontela, A., 2006. Effects of $\mathrm{Cu}$ on plasma cortisol and cortisol secretion by adrenocortical cells of rainbow trout, Oncorhynchus mykiss. Aquat. Toxicol., 59-65.

[15]. Ghazaly, K.S., 1992. Hematological and physiological responses to sublethal concentrations of cadmium in a freshwater teleost, Tilapia zillii. Water Air Aoli Pollut., 64, 551-559.

[16]. Gill, T.S., Pant, J.C., 1981. Effect of sublethal concentration of mercury in a teleost, Puntius conchonius, biochemical and haematological responses. Indian J. Exp. Biol., 19, 571-573.

[17]. Glover, C.N., Petri, D., Tollefsen, K.E., Jorum, N., Richard, D., Handy, Marc, H.G., Berntssen, 2007. Assessing the sensitivity of atlantic salmon (Salmo salar) to dietary endosulfan exposure using tissue biochemistry and histology. Aquat. Toxicol., 84, 346-355.

[18]. Hall, M.R., Van Ham, E.H., 1998. The effect of different types of stress on blood glucose in the giant tiger prawn penaeus monodon. J. World Aquat. Soc., 29, 290-299.

[19]. Hota, S., 1995. Toxic effect of arsenic on haemato-biochemical abnormalities in, Channa punctatus (Bloch). J. Ecotoxicol. Environ. Monit., 5(4), 249-255.

[20]. Jensen, F.B., 1995. Uptake and effects of nitrite in animals. IN: Walsh, P.J., Wright, P., (Eds.), Nitrogen Metabolism and Excretion. CRC Press, Boca Raton, pp. 289-303.

[21]. Jensen, F.B., 2003. Nitrite disrupts multiple physiological functions in aquatic animals. Comp Biochem Physiol. A, 135, 9-24. 
[22]. Kavitha, C., Malarvizhi, A., Senthil Kumaran, S., Ramesh, M., 2010. Toxicological effects of arsenate exposure on hematological, biochemical and liver transaminases activity in an Indian carp, catla catla. Food Chem. Toxicol., 48, 2848-2854.

[23]. Kenedy,C.J.,Farrell,A.P.,2005.Ion homeeostasis and interrental stress response in juvenile pacific herring,clupes pallasi,exposed to the water-soluble fraction of crude oil.J.Exp.Mar.Biol.Ecol.,323,43-56.

[24]. Knox,D.,Walton,M.J.,Cowey,C.B.,1980.Distribution of enzymes of glycolysis and gluconeogenesis in fish tissues. Mar. Biol., 56, $7-10$.

[25]. Kroupova, H., Machova, J., Piackova, V., Blahova, J., Dobsikova, R., Novotny, L., Svobodova, Z., 2008. Effects of subchronic nitrite exposure on rainbow trout (Onocorhynchus mykiss). Ecotoxicol. Environ. Saf.71, 813-820.

[26]. Lehninger, A.L.(Ed.), 1978. Biochemistry. Kalyani, Ludhiana, New Delhi, pp.223-236.

[27]. Lopes, P.A., Pinherio, T., Santos, M.C., Mathias, M., Collares-Pereira, M.J., Viegas- Crespo, A.M., 2001. Response of antioxidant enzymes in freshwater fish populations (Leuciscus alburnoides complex) to inorganic pollutants exposure. Sci. Total Environ., 280, $153-163$.

[28]. Lopez-Olmeda, J.F., Egea- Alvarez, M., Sanchez-Vazquez, F.J.,2009. Glucose tolerance in fish: Is the daily feeding time important? Physiol. Behav., 96, 631-636.

[29]. Margiocco, C., Arillo, A., Mensi, P., Schenone, G., 1983. Nitrite bioaccumulation in Salmo gairdneri. Rich and hematological consequences. Aquat. Toxicol., 3, 261-270.

[30]. Martin Deva Prasath, P., Arivoli, S., 2008. Biochemical study of freshwater fish catla catla with reference to mercury chloride. Iranian J. Env. Health Sci.Eng., 5(2), 109-116.

[31]. Martinez, C.B.R., Souza, M.M.,2002. Acute effects of nitrite on ion regulation in two neotropical fish species. Comp. Biochem. Physiol.A: Mol. Inte. Physiol., 133(1), 151-160.

[32]. Miron, D., Pretto, A., Crestani, M., Glusczak, L., Schetinger, M., Loro, V.L., Morsch, V., 2008. Biochemical effects of clomazone herbicide on piava (Leporinus obtusidens). Chemosphere, 74, 1-5.

[33]. Mommsen, T.P., Vijayan, M.M., Moon, T.W., 1999. Cortisol in teleosts: dynamics mechanisms of action, and metabolic regulation. Rev. Fish Biol. Fish., 211-268.

[34]. Monterio, D.A., Rantin, F.T., Kalinin, A.L., 2010. Inorganic mercury exposure: toxicological effects, oxidative stress biomarkers and bioaccumulation in the tropical freshwater fish matrinxa, Brycon amazonicus (Spix and Agassiz, 1829). Ecotoxicol., 19, 105123 .

[35]. Moon, T.W., 2001. Glucose intolerance in teleost fish: fact or fiction? Comp. Biochem. Physiol. B, 129, 243-249.

[36]. Moraes, G., Avilez,I.M., Hori, T.S.F., 2006. Comparison between biochemical responses of the teleost pacu and its hybrid Tambacu.Braz.J. Biol., 66(4), 1103-1108.

[37]. Nakano, T., Tomlinson, N., 1967. Catecholamine and carbohydrate concentrations in rainbow trout, Saimo gairdneri in relation to physical disturbance. J. Fish. Res. Bd. Can., 24, 1701-1715.

[38]. Oruc, E., Uner, N., 1999. Effects of 2,4- diamin on some parameters of protein and carbohydrate metabolisms in the serum, muscle and liver of Cyprinus carpio (L.). Environ. Pollut., 105, 267-272.

[39]. Osman, W.G.M., Koutb, M., Sayed, A.E.D.H., 2010. Use of hematological parameters to assess the efficiency of quince (Cydonia oblonga Miller) leaf extract in alleviation of the effect of ulttaviolet - A radiation on African catfish Clarias gariepinus (Burchell, 1822).J. Photochem. Photobiol.B: Biol., 99,1-8.

[40]. Philip, G.H., Reddy, P.M., Sridevi, G., 1995. Cypermethrin-induced in vivo alterations in the carbohydrate metabolism of freshwater fish, Labeo rohita. Ecotoxical. Environ. Saf., 31(2), 173-178.

[41]. Ramesh, M., Saravanan, M., 2008. Hematological and biochemical responses in a freshwater sih Cyprinus carpio exposed to chloropyrifos.Int.J.Integr.Biol.,3(1), 80-83.

[42]. Ramesh, M., Sivakumari, K.,Kanagaraj, M.K., Manavalaramanujam, R., 1994.Impact of acute zinc sulphate toxicity and salinity stress on the carbohydrate metabolism in Oreochromis mossambicus during different exposure periods. Indian J. Fish., 41(1), 51-54.

[43]. Sahib,I.K.A., Sambasiva Rao,K.R.S., Ramana Rao,K.V.1982.Effect of malathion on protein synthethic potentiality of the tissues of the teleost, Tilapia mossambica (Peters), as measured through incorporation of 14Camino acids.Toxico.Lett.,20,63-67.

[44]. Sancho, E., Ferrando, M.D.,Andreu, E., 1997. Sublethal effects of and organophosphate insecticide on the European eel, Anguil la Anguilla. Ecotopxicol.Environ. Saf., 36, 57-65

[45]. Saravanan, M., Karthika, S., Malarvizhi, A., Ramesh, M., 2011. Ecotoxicological impacts of clofibric acid and diclofenac in common carp(Cyprinus carpio) fingerlings: Hematological, biochemical, ionoregulatory and enzymological responses. J. Haz. Mater., 195, 188-194.

[46]. Sastry, K.V., Siddique, A.A., 1984. Some Haematological, biochemical and enzymological parameters of a fresh water teleost fish Channa punctatus exposed to sublethal concentrations of quinolphos. Pest. Biochem. Physiol., 22, 8-13.

[47]. Saxena, K.K., Gupta, P., 2005. Pyrethroids induced toxicity to muscle glycogen contents in Channa punctatus. Proc.Nalt.Acad.Sci.India., 75(2), 103-106.

[48]. Siikavuopio, S.I., Saether,B.S.,2006. Effects of chronic nitrite exposure on growth in juvenile Atlantic cod, Gadus morhua. Aquaculture, 255, 351-356.

[49]. Smet, D.H., Blust, R.,2001. Stress responses and changes in protein metabolism in carp Cyprinus carpio during cadmium exposure. Ecotoxicol.Environ.Saf., 48,255-262.

[50]. Sobha, K., Poornima, A., Harini, P., Veeraiah,K. 2007. A study on biochemical changes in the freshwater fish, Catla catla(Hamilton) exposed to the heavy metal toxicant cadmium chloride. Kathmandu Univ.J.Sci.Eng.Technol., 1(4).

[51]. Strik, J., De Iond, H., Van Rijn, J., Wuite, T., 1975. Toxicity of chromium (VI) in fish, with special defences to organ weight, liver and plasma enzyme activities, blood parameters and histological alteration. Elsevier Scientific, Amsterdam.

[52]. Teles, M., Maria, V.L., Pacheco, M., Santos, M.A., 2003. Anguilla anguilla (L.) plasma cortisol lactate and glucose responses to abietic acid dehydroabietic acid and retene. Environ. Int., 29, 995-1000.

[53]. Tiwari, S., Singh, A., 2005. Alterations in carbohydrates and the protein metabolism of the harmful freshwater vector snail Lymnaea acuminata induced by the euphorbia tirucalli latex extract. Environ. Res., 99, 378-386.

[54]. USEPA, 2001. Update of ambient water quality criteria for cadmium. EPA-822-R-01-001, Office of Water, US Environmental Protection Agency., Washington, DC, pp. 2-9.

[55]. Velisek, J., Jurcikova, j., Dobsikova, R., Svobodova, Z., Piackova, V., Machova, J., Novotny, L., 2007. Effects of deltamethrin on rainbow rout (Oncorhynchus mykiss). Environ. Toxicol. Pharmacol., 23, 297-301.

[56]. Venkateswara Rao, J., 2006. Biochemical alterations in euryhaline fish, Oreochromis mossambicus exposed to sub-lethal concentrations of an organophosphorus insecticide, monocrotophos. Chemosphere, 65(10), 1814-1820. 
[57]. Vijayavel, K., Rani, E.F., Anbuselvan, C., Balasubramanian, M.P., 2006. Interactive effects of monocrotophos and ammonium chloride on the freshwater fish Oreochromis mossambicus with reference to lactate/pyruvate ratio. Pestic. Biochem. Physiol., 86, $157-161$

[58]. Watson, T.A., McKeown, B.A., 1976. The effect of sublethal concentrations of zinc on growth and plasma glucose levels in rainbow trout, Salmo gairdneri (Richardson). J. Wildl. Dis., 12, 263-270.

[59]. Yildiz, H.Y., Benil, A.C.K., 2004. Nitrite toxicity to crayfish, Astacus leptodactylus, the effects of sublethal nitrite exposure on hemolymph nitrite, Total hemocyte counts and hemolymph glucose. Ecotoxicol. Environ. Saf., 59, 370-375. 